\title{
Brain-Derived Neurotrophic Factor Modulation of GABAergic Synapses by Postsynaptic Regulation of Chloride Transport
}

\author{
Rinda A. Wardle ${ }^{1,2}$ and Mu-ming Poo ${ }^{1}$ \\ ${ }^{1}$ Division of Neurobiology, Department of Molecular and Cell Biology, University of California, Berkeley, California 94720-3200, and ${ }^{2}$ Division of Biology, \\ University of California at San Diego, La Jolla, California 92093-0357
}

\begin{abstract}
Brain-derived neurotrophic factor (BDNF) potentiates excitatory synapses in a variety of systems by promoting presynaptic transmitter release. The existing evidence indicates that BDNF attenuates inhibitory transmission, but reports differ considerably in their characterization of the effect and proposed mechanisms. We examined the effects of exogenously applied BDNF on EPSCs and IPSCs recorded from functionally identified neurons in dissociated rat hippocampal cultures. When recording from glutamatergic neurons, we found that BDNF exerted differential effects at excitatory versus inhibitory synapses: increasing amplitude of EPSCs but slightly decreasing that of IPSCs. Furthermore, when recording from GABAergic neurons, we found that BDNF increased the IPSC amplitude. That these differential BDNF effects reflect distinct presynaptic and postsynaptic mechanisms was suggested by the BDNF-induced changes in miniature EPSCs and IPSCs. An increased mini-frequency was found at all synapses, indicating elevated presynaptic transmitter secretion; a change in the amplitude of mini-IPSCs was found at GABAergic cells, suggesting postsynaptic modulation of GABA responses. Selective postsynaptic mechanisms were further examined by comparing the effect of BDNF on GABA-induced currents recorded from glutamatergic versus GABAergic cells. For GABAergic but not glutamatergic postsynaptic cells, BDNF induced a shift in the reversal potential ( $\left.E_{\text {IPSC }}\right)$ toward more positive levels, hence reducing the inhibitory action of IPSCs. This BDNF-induced effect correlates with the existing level of furosemide-sensitive $\mathrm{K}^{+}-\mathrm{Cl}^{-}$transport activity in the postsynaptic cell. Thus, BDNF may decrease the efficacy of inhibitory transmission by acute postsynaptic downregulation of $\mathrm{Cl}^{-}$transport, in addition to its well known presynaptic effect.
\end{abstract}

Key words: BDNF; inhibitory synapses; GABAergic transmission; chloride transporter; synaptic plasticity; hippocampal cultures

\section{Introduction}

Neurotrophins are crucial for the survival and differentiation of neurons (Levi-Montalcini, 1987; Lewin and Barde, 1996) and are known to modulate a variety of synapses (McAllister et al., 1999; Poo, 2001). Neurotrophins serve long-term trophic functions by regulating expression of synaptic proteins (Wang et al., 1995; Narisawa-Saito et al., 1999; Loeb et al., 2002) and maturation of synaptic properties (Wang et al., 1995; Liou et al., 1997). They also acutely modulate the efficacy of basal synaptic transmission at developing neuromuscular junctions in cell cultures (Lohof et al., 1993) and at central excitatory synapses in hippocampal and cortical cultures (Lessmann et al., 1994; Levine et al., 1995; Li et al., 1998), acute slices (Kang and Schuman, 1995; Akaneya et al., 1997), and in vivo (Messaoudi et al., 1998). In addition, brainderived neurotrophic factor (BDNF), a member of the neurotrophin family, plays an important role in activity-induced longterm potentiation (LTP) in the hippocampus (Korte et al., 1995; Figurov et al., 1996; Patterson et al., 1996).

The mechanisms for neurotrophin-induced synaptic modu-

Received Jan. 13, 2003; revised July 31, 2003; accepted Aug. 12, 2003. This work was supported by National Institutes of Health Grant NS37831.

Correspondence should be addressed to M-m.Poo at the above address. E-mail: mpoo@uclink.berkeley.edu. Copyright $\odot 2003$ Society for Neuroscience $\quad$ 0270-6474/03/238722-11\$15.00/0 lation have been most extensively studied at excitatory synapses. With a few exceptions (Levine et al., 1995; Kovalchuk et al., 2002), neurotrophin effects have been attributed to increased presynaptic transmitter release. They have also been associated with activation of Trk receptor tyrosine kinase (Lohof et al., 1993), PI-3 (phosphoinositide-3) kinase (Yang et al., 2001) and MAP (mitogen-activated protein) kinase (Jovanovic et al., 1996), and elevation of cytoplasmic $\mathrm{Ca}^{2+}$ (Zhang and Poo, 2002). The downstream actions of these cytoplasmic signals may increase phosphorylation of synaptic vesicle-associated proteins (Jovanovic et al., 2000), causing enhanced transmitter loading, vesicle mobilization, or secretion at excitatory synapses. Interestingly, the existing evidence indicates that neurotrophins reduce the efficacy of inhibitory transmission (Kim et al., 1994; Tanaka et al., 1997; Frerking et al., 1998; Brunig et al., 2001, Rivera et al., 2002). Together, these reports suggest that BDNF-induced acute synaptic modulation is specific to presynaptic neuron type. In addition, the effect of BDNF at excitatory synapses is specific to postsynaptic cell type. In hippocampal cultures, BDNF induces elevated glutamate release at synapses with glutamatergic (E) but not GABAergic (I) postsynaptic cells (Schinder et al., 2000). Analogously, LTP can be induced in hippocampal cultures (Bi and Poo, 1998) and slices (McMahon and Kauer, 1997; Maccaferri et al., 1998) with glutamatergic but not GABAergic 
postsynaptic cells. It is unknown whether the modulatory effect of BDNF on GABAergic synapses is also specific to the postsynaptic cell type.

In the present study, we demonstrated that BDNF exerts opposite modulatory effects on glutamatergic and GABAergic synapses in hippocampal cultures. In addition, we found that the effect of BDNF on GABAergic synapses depends on the postsynaptic cell type. Although BDNF modulates presynaptic transmitter release at GABAergic synapses on both glutamatergic and GABAergic postsynaptic cells, BDNF acts postsynaptically to reduce inhibition only at GABAergic synapses on GABAergic postsynaptic cells. This action is mediated by a BDNF-induced shift in the reversal potential $\left(E_{\text {IPSC }}\right)$ for $\mathrm{Cl}^{-}$currents toward more positive levels, an effect that correlates with a rapid downregulation of $\mathrm{K}^{+}-\mathrm{Cl}^{-}$cotransporter activity. These findings demonstrate a novel mechanism for BDNF modulation of GABAergic synapses.

\section{Materials and Methods}

Culture preparation. Low-density cultures of dissociated hippocampal neurons were prepared from embryonic day 18 (E18) to E20 rat embryos as described previously ( $\mathrm{Bi}$ and Poo, 1998). Hippocampi were trypsinized for $20 \mathrm{~min}$ at $37^{\circ} \mathrm{C}$ and then gently triturated. Dissociated neurons were plated at 25,000-100,000 cells/ml on poly-L-lysine-coated glass coverslips in $35 \mathrm{~mm}$ Petri dishes. The plating medium used was DMEM (BioWhittaker, Walkersville, MD) supplemented with 10\% fetal calf serum (Hyclone, Logan, UT), 10\% Ham's F-12 with glutamine (BioWhittaker) and $50 \mathrm{U} / \mathrm{ml}$ penicillin-streptomycin (Sigma, St. Louis, $\mathrm{MO}$ ). The culture medium was supplemented with $20 \mathrm{~mm} \mathrm{KCl} 24 \mathrm{hr}$ after plating. Both glia and neurons are present under these conditions. Neurons were recorded after 10-14 d in culture.

Electrophysiology. Double whole-cell perforated-patch or breakthrough recordings were simultaneously made from pairs of reciprocally connected neurons in culture as described previously (Bi and Poo, 1998). Recording pipettes were prepared from glass microcapillaries (VWR Scientific, Brisbane, CA) with a resistance of 2-4 M . Internal solutions differed in various experiments and are described in detail below. All experiments were performed at room temperature in an external bath solution containing the following (in $\mathrm{mM}$ ): $150 \mathrm{NaCl}, 3 \mathrm{KCl}, 3 \mathrm{CaCl}_{2}, 2$ $\mathrm{MgCl}_{2}, 10$ HEPES, and 5 glucose, $\mathrm{pH} 7.4$ (310 mOsm). Neurons were visualized by phase-contrast optics (Nikon Diaphot; Nikon, Tokyo, Japan). Recordings were performed with two patch-clamp amplifiers (Axopatch 200B; Axon Insturments, Foster City, CA). Signals were filtered at $5 \mathrm{~Hz}$ using amplifier circuitry. Data was acquired and analyzed using Axoscope 8.0 (Axon Instruments). Series resistance was assessed at $5 \mathrm{~min}$ intervals and compensated at $75 \%$ throughout the experiment. Experiments were rejected if changes in series resistance exceeded $10 \%$. Unless otherwise noted, average values are expressed as mean \pm SEM, and statistical analyses were performed using one-tailed Student's $t$ tests, either paired or unpaired as noted. BDNF (PeproTech, Rocky Hill; NJ) was added directly to the recording bath for a final concentration of 100 $\mathrm{ng} / \mathrm{ml}$ in experiments that did not require perfusion of the culture. When cells were being continuously perfused, the bath solution was recycled once BDNF had been added for a final concentration of $100 \mathrm{ng} / \mathrm{ml}$. We found no difference in results for these two procedures of BDNF application. All recordings of currents induced by focally applied transmitter were made with constant perfusion to avoid desensitization of transmitter receptors and toxicity to the cell.

Recordings of EPSCs and IPSCs. To assess synaptic connectivity, the presynaptic neuron was stimulated at a low frequency $(0.03-0.05 \mathrm{~Hz})$ with a $1 \mathrm{msec}$ step depolarization from -70 to $+30 \mathrm{mV}$ in voltage-clamp mode. We identified EPSCs and IPSCs by their characteristic decay times ( $\sim 10$ and $40 \mathrm{msec}$, respectively), reversal potentials ( -5 to $5 \mathrm{mV}$ and -70 to $-40 \mathrm{mV}$, respectively), and, in some cases, their sensitivity to 6-cyano-7-nitroquinoxaline-2,3-dione (CNQX) $(10 \mu \mathrm{M})$ or bicuculline methiodide (15 $\mu \mathrm{M}$; Research Biochemicals, Natick, MA), respectively. Experiments were performed only if both the presynaptic and postsyn- aptic cell type could be identified. For most recordings, neurons were voltage clamped $\left(V_{\mathrm{h}}\right)$ at $-70 \mathrm{mV}$, resulting in inward currents for both EPSCs and IPSCs. For perforated-patch recordings of EPSCs and IPSCs, pipettes were tip filled with internal solution and then backfilled with internal solution containing gramicidin D $(25 \mu \mathrm{g} / \mathrm{ml}$; Sigma $)$ or amphotericin B (200 $\mu \mathrm{g} / \mathrm{ml}$; Calbiochem, San Diego, CA). The internal solution for gramicidin $\mathrm{D}$ perforated-patch recordings contained the following (in $\mathrm{mm}$ ): $150 \mathrm{KCl}$ and $10 \mathrm{HEPES}$. The internal solution for amphotericin B perforated-patch recordings contained the following (in $\mathrm{mM}$ ): 154 K-gluconate, $9 \mathrm{NaCl}, 1 \mathrm{MgCl}_{2}, 10 \mathrm{HEPES}$, and $0.2 \mathrm{EGTA}$. All perforatedpatch recordings of EPSCs were made with amphotericin B. Perforatedpatch recordings of IPSCs were made with either gramicidin D or amphotericin B. Gramicidin D forms pores permeable to monovalent cations and small uncharged molecules but not to $\mathrm{Cl}^{-}$, permitting reliable recordings of GABAergic currents (Kyrozis and Reichling, 1995; Owens et al., 1996). However, because of the difficulty in maintaining stable access resistance during long-term recordings with gramicidin $\mathrm{D}$, we performed additional experiments using amphotericin $\mathrm{B}$ as the perforating agent. Amphotericin B forms pores that are partially permeable to $\mathrm{Cl}^{-}$, which can cause an initial perturbation of $\left[\mathrm{Cl}^{-}\right]_{\mathrm{i}}$. However, we found that a new steady-state $\left[\mathrm{Cl}^{-}\right]_{\mathrm{i}}$ was rapidly established after perforation. Therefore, we started experiments only after recording 10-20 min of control period, during which the IPSC amplitude and $E_{\text {IPSC }}$ remained constant, indicating that a new steady-state $\left[\mathrm{Cl}^{-}\right]_{\mathrm{i}}$ had been established. For breakthrough whole-cell recordings of EPSCs and IPSCs, pipettes were backfilled with internal solution containing the following (in mM): $135 \mathrm{~K}$-gluconate, $15 \mathrm{KCl}, 5 \mathrm{NaCl}, 0.5 \mathrm{EGTA}, 10 \mathrm{HEPES}$, and $2 \mathrm{Mg}$-ATP. No difference was observed between experiments performed with amphotericin B or gramicidin D perforated-patch or breakthrough whole-cell recording. The synaptic reversal potential of IPSCs was determined by varying the $V_{\mathrm{h}}$ of the postsynaptic cell in $5-10 \mathrm{mV}$ increments from -80 to $-50 \mathrm{mV}$ and measuring the resulting IPSC amplitude. A best-fit line for the current-voltage $(I-V)$ relationship was calculated using a linear regression, and the interpolated intercept of this line with the abscissa was taken as the reversal potential. The slope of the same line was taken as the respective slope conductance.

Recordings of transmitter-induced currents. After the cell type was determined using synaptically evoked responses, glutamate or GABA was focally applied at the soma of the identified cell, and transmitter-induced currents were recorded by puffing transmitter pulses $(100 \mathrm{~mm}, 1 \mathrm{msec}$, $10-20$ psi) through a micropipette ( $2 \mathrm{M} \Omega$; VWR Scientific) at a $30 \mathrm{sec}$ interval, using an electrically gated Picospritzer (General Valve, Fairfield, NJ). Glutamate (100 mM) was puffed at a $90 \mathrm{sec}$ interval to reduce potential toxic effects on the cells. All transmitter-induced currents were recorded using the perforated-patch method. Either gramicidin D or amphotericin B was used as the perforating agent for GABA-induced current recordings, with similar results. All glutamate-induced current recordings were performed with amphotericin B perforation.

Recordings of miniature EPSCs and IPSCs. After the cell type had been identified using the criteria described above, the bath solution was replaced with one that contained tetrodotoxin (TTX) (1 $\mu \mathrm{M}), 0.05 \%$ BSA, and either bicuculline $(15 \mu \mathrm{M})$ or CNQX $(10 \mu \mathrm{M})$ to record miniature EPSCs (mEPSCs) or mIPSCs, respectively. Recordings of mEPSCs were made using the amphotericin B perforated-patch method described above. Because the amplitudes of mIPSCs with $V_{\mathrm{h}}$ of $-70 \mathrm{mV}$ were too small to be consistently detected, mIPSCs were recorded as outward currents at $V_{\mathrm{h}}$ of $0 \mathrm{mV}$. To stabilize the cells while voltage clamped at 0 $\mathrm{mV}$, mIPSCs were recorded in breakthrough mode using whole-cell internal solution (described above) that replaced $\mathrm{K}^{+}$-gluconate with $\mathrm{Cs}^{+}$gluconate to block $\mathrm{K}^{+}$channels. A few whole-cell recordings of mIPSCs were made with $V_{\mathrm{h}}$ of $-70 \mathrm{mV}$ by increasing the $\left[\mathrm{Cl}^{-}\right]_{\mathrm{i}}(155 \mathrm{~mm})$ to change $E_{\text {IPSC }}$ to a level approaching $0 \mathrm{mV}$, thus allowing us to record amplified inward mIPSCs at $V_{\mathrm{h}}$ of $-70 \mathrm{mV}$. This recording technique allowed us to investigate potential presynaptic BDNF effects on mIPSC frequency recorded from I $\rightarrow$ I synapses, which were masked when recording at $0 \mathrm{mV}$ because of the postsynaptic BDNF effects on mIPSC 
amplitude. However, this recording technique did not allow us to observe postsynaptic changes because the elevated $\left[\mathrm{Cl}^{-}\right]_{\mathrm{i}}(155 \mathrm{~mm})$ in the whole-cell pipette solution rendered any BDNF-induced postsynaptic changes in $\left[\mathrm{Cl}^{-}\right]_{\mathrm{i}}$ too small in percentage to cause a noticeable change in $E_{\text {IPSC }}$ (average BDNF-induced changes in $\left[\mathrm{Cl}^{-}\right]_{\mathrm{i}}$ were found to be $4-5 \mathrm{~mm}$ in experiments using either gramicidin or amphotericin perforated-patch recording, as estimated by Nernst's equation and known values for $\left[\mathrm{Cl}^{-}\right]_{\mathrm{o}}$ and BDNF-induced changes in $E_{\text {IPSC }}$ ).

Immunocytochemistry. Hippocampal cultures prepared as described above were washed with PBS two to three times before and after each of the following steps. Cultures were fixed with $4 \%$ paraformaldehyde for $20 \mathrm{~min}$, permeabilized with $0.2 \%$ Triton X-100 for $20 \mathrm{~min}$, incubated for $90 \mathrm{~min}$ with rabbit anti-KCC2 antibody (Upstate Biotechnology, Lake Placid, NY) diluted (1:200) in 2\% PBS-BSA, incubated for 60 min with Alexa Fluor 568 goat anti-rabbit secondary antibody (Molecular Probes, Eugene, OR) diluted (1:1000) in 2\% PBS-BSA, and mounted with Prolong Antifade (Molecular Probes). Images of fluorescent neurons were acquired using a Leica (Nussloch, Germany) confocal imaging system (TCS SP) equipped with a krypton gas ion laser and a Leica inverted microscope (DM IRBE) fitted with a Leica $40 \times$ objective (PL Apo; $1.25-0.75$ oil immersion).

\section{Results}

The effect of BDNF on GABAergic synapses depends on the postsynaptic cell type

Synaptic modulation by BDNF was examined at both glutamatergic and GABAergic synapses in cultures of dissociated rat hippocampal neurons. Simultaneous recordings of two reciprocally connected neurons were made using whole-cell recording methods. Because the BDNF effect on glutamatergic synapses has been shown to be target-cell specific (Schinder et al., 2000), we recorded from neuron pairs only when both presynaptic and postsynaptic cells could be unequivocally identified as either glutamatergic (E) or GABAergic (I). The cell type of the neuron was determined by sequentially recording synaptic currents evoked by stimulation of each neuron in the pair. EPSCs and IPSCs were identified by their characteristic time course, reversal potential, and, in some cases, their sensitivity to CNQX and bicuculline, which block AMPA and $\mathrm{GABA}_{\mathrm{A}}$ receptors, respectively (see Materials and Methods).

In the first set of experiments, we examined the effects of bath-applied BDNF on the efficacy of both glutamatergic and GABAergic synapses. Recordings were made with gramicidin D or amphotericin B perforated patch or with breakthrough whole cell. Similar results were obtained with all three methods as long as a stable control recording was achieved before the application of BDNF (see Materials and Methods). Presynaptic specificity of the action of BDNF was determined by comparing the effects of BDNF on EPSCs and IPSCs observed only in glutamatergic neurons $(\mathrm{E} \rightarrow \mathrm{E}$ vs $\mathrm{I} \rightarrow \mathrm{E})$. Postsynaptic specificity of BDNF actions was determined by comparing the effects of BDNF on IPSCs observed in glutamatergic versus GABAergic neurons ( $\rightarrow \mathrm{E}$ vs $\mathrm{I} \rightarrow \mathrm{I}$ ). Neurons were voltage clamped at $-70 \mathrm{mV}$, at which most IPSCs were inward currents with distinctively longer decay times than EPSCs. After a 10-20 min control period of stable EPSC or IPSC recording, BDNF (100 ng/ml) was applied to the culture by either direct bath addition or constant perfusion. In agreement with previous findings (Lessmann et al., 1994; Levine et al., 1995; Li et al., 1998; Schinder et al., 2000), the amplitude of EPSCs recorded at $\mathrm{E} \rightarrow \mathrm{E}$ synapses increased within the first $10-15 \mathrm{~min}$ and reached a final level of $129 \pm 7.3 \%(n=12)$ (Fig. $1 A, D, E)$ of the control level. In contrast, the amplitude of IPSCs recorded from I $\rightarrow$ E synapses showed a slight reduction over the same time course $(87 \pm 4.5 \%$ of the control; $n=19$ ) (Fig. $1 B, D, E$ ), suggesting a differential BDNF effect that depends on the presynaptic cell type. Surprisingly, the amplitude of IPSCs recorded from I $\rightarrow$ I synapses showed a marked increase in response to BDNF ( $154 \pm 6.7 \%$ of the control; $n=20$ ), starting within 5-10 min after the addition of BDNF (Fig. 1C-E), indicating a postsynaptic cell-type specificity for BDNF modulation of IPSCs. This increase in the amplitude of inward (depolarizing) IPSCs represents a reduction of inhibition at these synapses. Together, these experiments indicate that the modulation of synaptic 


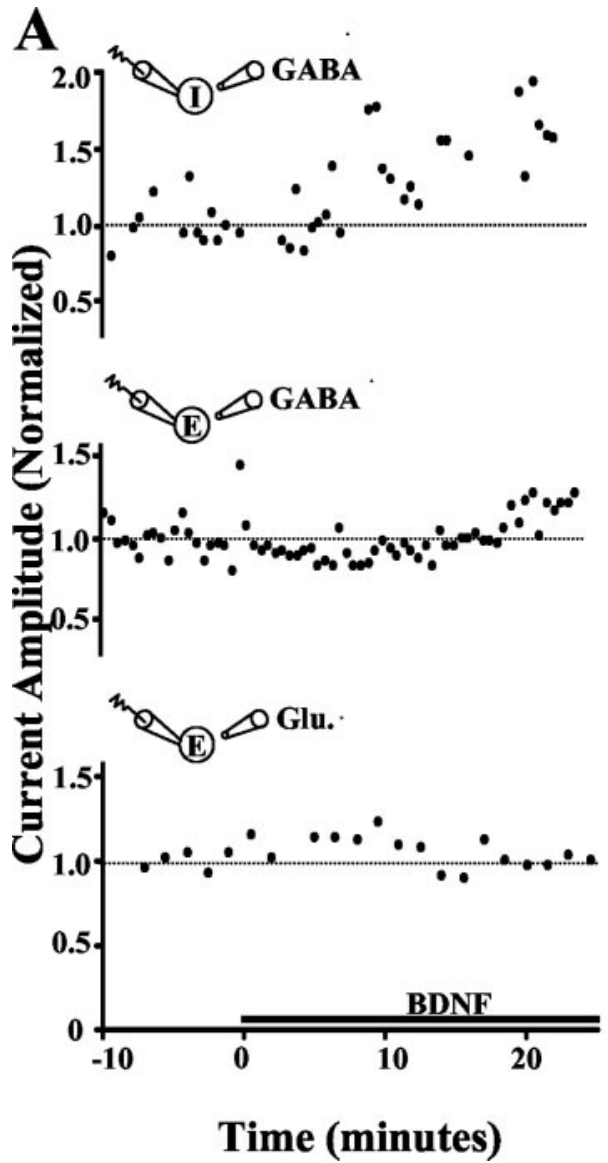

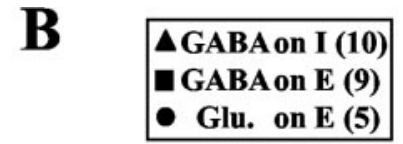
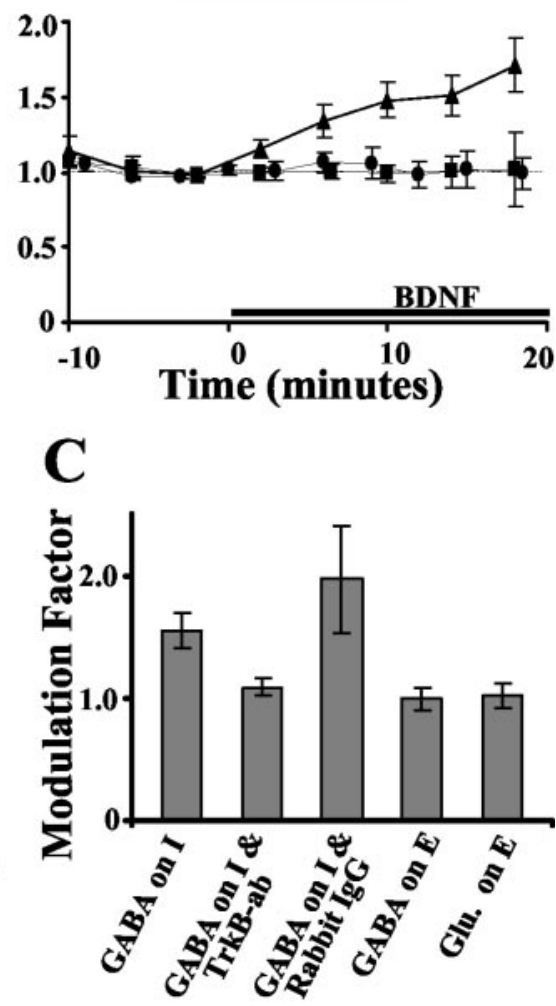

Figure 2. The effects of BDNF on transmitter-induced currents. $A$, Example of $I_{\mathrm{GABA}}$ recorded from GABAergic (top) and glutamatergic (middle) cells and $I_{\text {glu }}$ recorded from glutamatergic cells (bottom). $I_{G A B A}$ were recorded using gramicidin $D$, and $I_{\text {glu }}$ were recorded using amphotericin B. BDNF was added at $t=0$. B. Summary of the normalized amplitude of $I_{\mathrm{GABA}}$ and $I_{\text {glu }}$ at various times before and after BDNF treatment (black bar). At GABAergic cells, BDNF caused an increase in $I_{\text {GABA }}$ amplitude $(164 \pm 13 \%$ of control), but at glutamatergic cells, BDNF caused no significant change in $I_{\text {GABA }}$ or $I_{\text {glu }}$ amplitude (94 \pm 10 and $92 \pm 6 \%$, respectively). No significant difference was found between $I_{G A B A}$ recorded with gramicidin $D$ and amphotericin $B$, and the data were pooled. C, Summary of the average BDNF effect on transmitter-induced currents. Modulation factor defined as the ratio between the mean transmitter-induced current amplitude 10-20 min after BDNF application and that during the last 10 min of the control period. BDNF caused an increase in $I_{\mathrm{GABA}}$ recorded from GABAergic cells $(1.54 \pm 0.15 ; p<0.001 ; n=10)$, but this effect was blocked in cells that had been preincubated with a TrkB antibody $(20 \mu \mathrm{g} / \mathrm{ml} ; 1.09 \pm 0.08 ; n=5 ; p>0.1)$. Preincubation with rabbit $\operatorname{lgG}(50 \mu \mathrm{g} / \mathrm{ml})$ did not block the BDNF effect $(1.96 \pm 0.43 ; n=4 ; p<0.05)$. Glu, Glutamate; ab, antibody.

transmission by BDNF is unique to each of four different synaptic configurations, suggesting both presynaptic and postsynaptic celltype specificity of BDNF action.

\section{BDNF effects on GABA-induced currents}

To determine whether the postsynaptic cell-type specificity of the effect of BDNF on IPSCs reflects a postsynaptic mechanism, we examined the effect of bath-applied BDNF on membrane currents induced by focally applied transmitter. Pairs of neurons were patched and identified. A GABA- or glutamate-containing micropipette was positioned near the surface of the soma, the transmitter was pressure ejected with a $1 \mathrm{msec}$ pulse at regular intervals (see Materials and Methods), and membrane currents were recorded (at $V_{\mathrm{h}}$ of $-70 \mathrm{mV}$ ) before and after application of BDNF. We found that BDNF treatment caused an increase in the amplitude of inward GABA-induced currents $\left(I_{\mathrm{GABA}}\right)$ recorded from GABAergic cells, with a time course and extent of increase similar to that observed for IPSCs at I $\rightarrow$ I synapses (Fig. 2A,B). The persistence of the BDNF effect was examined by monitoring the amplitude of $I_{\mathrm{GABA}}$ after removing BDNF by perfusion with fresh culture medium. In three of four cases, we found that the elevated $I_{\mathrm{GABA}}$ persisted for as long as a stable recording was made (5-15 min after washout). In contrast, BDNF had no effect on $I_{\mathrm{GABA}}$ or glutamate-induced currents $\left(I_{\text {glu }}\right)$ recorded from glutamatergic cells (Fig. 2A,B). This demonstrates a selective susceptibility of GABAergic neurons to BDNF-dependent modulation of $I_{\mathrm{GABA}}$, consistent with a potential postsynaptic BDNF effect at $\mathrm{I} \rightarrow \mathrm{I}$ synapses. The lack of any BDNF-induced change in $I_{\text {glu }}$ at glutamatergic neurons is consistent with a presynaptic mechanism for BDNF action on EPSCs at $\mathrm{E} \rightarrow \mathrm{E}$ synapses, whereas the lack of change of $I_{\mathrm{GABA}}$ in glutamatergic neurons confirms the postsynaptic specificity of the BDNF effect on IPSCs.

\section{BDNF acts postsynaptically through TrkB receptors}

To determine whether the observed BDNF effect on $I_{\mathrm{GABA}}$ recorded from GABAergic cells was attributable to activation of TrkB receptors, we examined the effect of BDNF on cells that were preincubated with an antibody raised against the extracellular domain of the TrkB receptor (amino acids 160-320; rabbit polyclonal). We found that preincubation with TrkB antibody for 15-20 min before recording blocked BDNF modulation of $I_{\mathrm{GABA}}$ amplitudes recorded from GABAergic cells (Fig. 2C). Preincubation with rabbit IgG had no effect on the BDNF-induced elevation of the $I_{\mathrm{GABA}}$ amplitude (Fig. 2C). The tyrosine kinase inhibitor $\mathrm{K} 252 \mathrm{a}$ is commonly used to demonstrate TrkB receptor involvement in an observed BDNF effect. We found that, in the presence of K252a, BDNF caused a marked decrease in $I_{\mathrm{GABA}}$ amplitude (data not shown), indicating that tyrosine kinase activity may be involved in the BDNF effect. However, $\mathrm{K} 252 \mathrm{a}$ is a general tyrosine kinase inhibitor, and both the $\mathrm{K}^{+}-\mathrm{Cl}^{-}$cotransporter $2(\mathrm{KCC} 2)$ and $\mathrm{GABA}_{\mathrm{A}}$ receptors are known to be regulated by tyrosine kinase activity (Dunne et al., 1998; Kelsch et al., 2001; Brandon et al., 2002). Thus, the above K252a effect may result from multiple actions on other tyrosine kinases besides TrkB.

\section{BDNF effects on mIPSCs also indicate}

\section{postsynaptic modulation}

To further study the loci of BDNF-induced synaptic modulation, mIPSCs and mEPSCs were analyzed before and after BDNF treatment. Functional identification of the postsynaptic cell type as glutamatergic or GABAergic was made before selective recording of mIPSCs or mEPSCs, using action potential blocker TTX, together with $\mathrm{CNQX}$ or bicuculline, respectively. At $\mathrm{E} \rightarrow \mathrm{E}$ synapses, the frequency of mEPSCs increased markedly after the BDNF treatment $(202 \pm 24 \%$ of the control), whereas the mEPSC amplitude distribution remained unchanged (Fig. 
$3 A, D)$. These results are consistent with previous reports (Lessmann et al., 1994; Li et al., 1998; Schinder et al., 2000).

The amplitude of inward mIPSCs recorded with $V_{\mathrm{h}}$ of $-70 \mathrm{mV}$ was too small to be consistently detected above the noise level because the $V_{\mathrm{h}}$ was only slightly more negative than the $E_{\text {IPSC }}$ for most cells. Recording with much more negative $V_{\mathrm{h}}$ increases the observed size of inward currents but is damaging to the cell. Therefore, mIPSCs were recorded at $V_{\mathrm{h}}$ of $0 \mathrm{mV}$ as amplified outward currents (see Materials and Methods). We found that BDNF caused a rapid increase in the mIPSC frequency at $\mathrm{I} \rightarrow$ E synapses $(193 \pm$ $45 \%$ of controls), without significant change in the distribution of MIPSC amplitudes (Fig. $3 B, D$ ). This is in sharp contrast to the BDNF-induced reduction of IPSC amplitude at $\mathrm{I} \rightarrow$ E synapses, because an increased mini-frequency usually suggests an increased release probability. As discussed later, however, the disparate changes in spontaneous and evoked release are not unprecedented.

When recording outward mIPSCs at $\mathrm{I} \rightarrow \mathrm{I}$ synapses $\left(V_{\mathrm{h}}\right.$ of $\left.0 \mathrm{mV}\right)$, we found that BDNF caused a reduction of the mIPSC amplitude $(79 \pm 1 \%$ of controls) and a marked decrease in the MIPSC frequency (30 $\pm 9 \%$ of controls) (Fig. 3C,D). The change in mIPSC amplitude is consistent with a postsynaptic effect. This BDNFinduced reduction of outward mIPSC currents at $V_{\mathrm{h}}$ of $0 \mathrm{mV}$ is reconciled with the previous finding of increased inward IPSCs and $I_{\mathrm{GABA}}$ at $-70 \mathrm{mV}$ if both resulted from a BDNF-induced shift in the reversal potential of $\mathrm{Cl}^{-}$currents toward more positive levels. The reduction of mIPSC frequency could in principle result from either a reduction in the release probability or, indirectly, the reduction in MIPSC amplitudes. Because of the skewed amplitude distribution of mIPSCs toward smaller events, reduction in mIPSC amplitudes would result in a disproportionately large decrease in the perceived frequency as a result of a loss of events with amplitudes below the detection threshold. To further test the latter possibility, mIPSC were recorded at $\mathrm{I} \rightarrow \mathrm{E}$ or $\mathrm{I} \rightarrow \mathrm{I}$ synapses at different clamping voltages ranging from 0 to $-15 \mathrm{mV}$ in $5 \mathrm{mV}$ decrements. We found that the decrease in MIPSC amplitude as the membrane potential approached the reversal potential was accompanied by a progressive decrease in the observed mIPSC frequency (Fig. $3 E$ ), in a manner that is quantitatively consistent with the idea that the observed decrease in mIPSC frequency and amplitude reflects a change in amplitude alone. The extent of the observed decrease in mIPSC frequency attributable to amplitude change could also have masked the presynaptic BDNF effects. In two cases in which we were able to record mIPSCs from GABAergic cells at $-70 \mathrm{mV}$, we indeed observed a robust increase in mIPSC
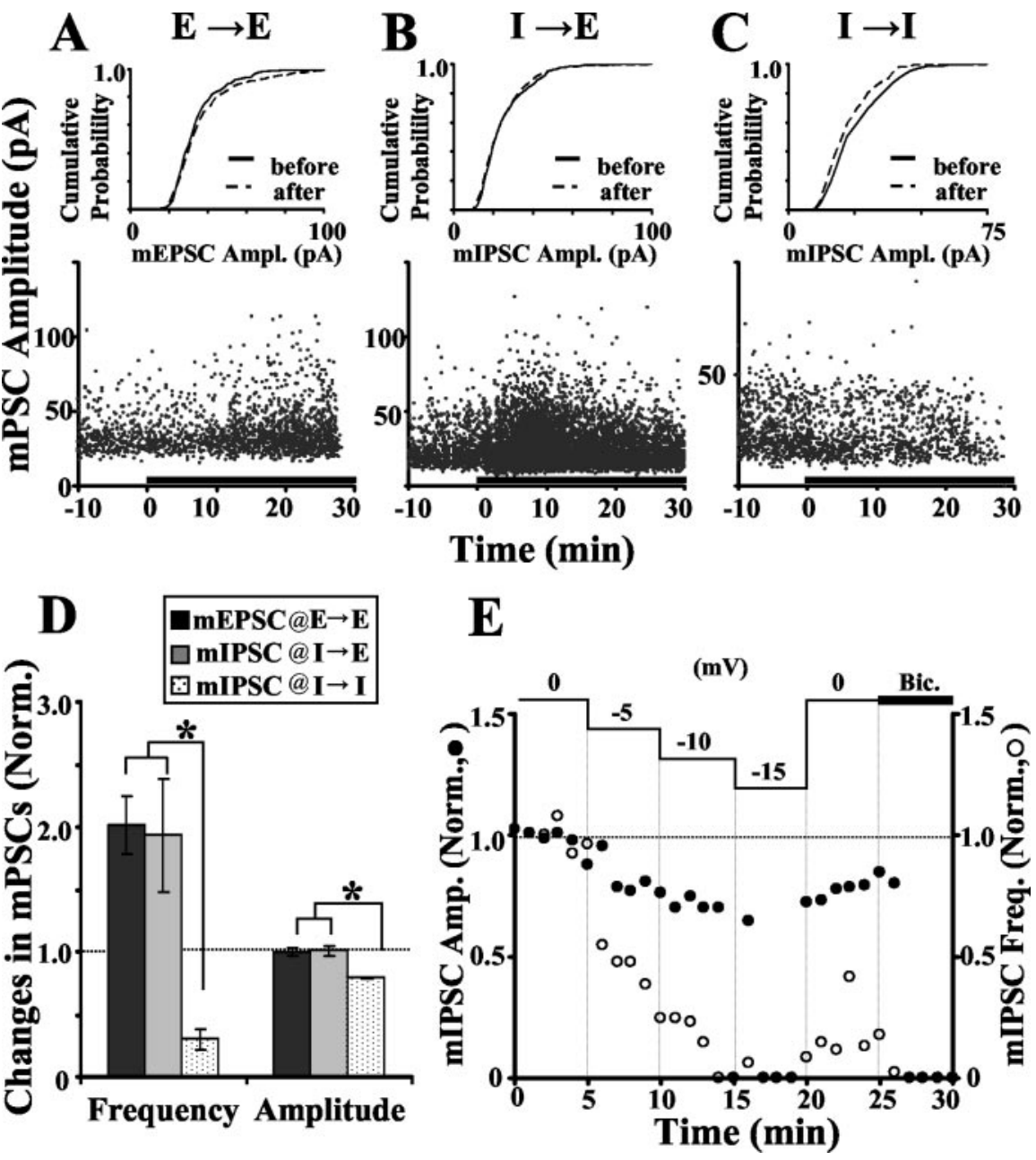

Figure 3. BDNF effect on miniature postsynaptic currents. $A$, Example of $m E P S C s$ at an $E \rightarrow E$ synapse. Bottom, Scatter plot of mEPSC amplitudes recorded before and after adding BDNF (black bar) in the presence of TTX and bicuculline. Top, Amplitude cant difference was found between distributions ( $p=0.13$; Kolmogorov-Smirnov test). Recording made with amphotericin $B$ $\left(V_{\mathrm{h}}\right.$ of $\left.-70 \mathrm{mV}\right)$. B, Example of mIPSCs at an $\mathrm{I} \rightarrow \mathrm{E}$ synapse in the presence of TTX and CNQX, using breakthrough whole-cell at $\mathrm{I} \rightarrow$ E before and after BDNF treatment ( $p=0.40$; Kolmogorov-Smirnov test). C, Example of mIPSC at $I \rightarrow I$ synapse, recorded similar to that described in $B$. Amplitude distributions show a significant difference before and after BDNF treatment $(p=0.008$ $(n=7)$, and $\mathrm{I} \rightarrow \mathrm{I}(n=4)$ synapses. Each bar represents the mean amplitude or frequency $15-30 \mathrm{~min}$ after the onset of BDNF

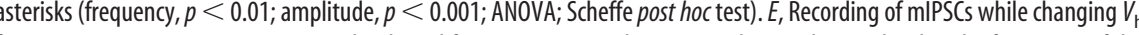
from 0 to $-15 \mathrm{mV}$ in $5 \mathrm{mV}$ steps. Amplitude and frequency averaged over $1 \mathrm{~min}$ bins and normalized to the first $5 \mathrm{~min}$ of the recording ( $t=0-5 \mathrm{~min})$. At $t=25 \mathrm{~min}$, bicuculline (Bic) was added to the recording solution.

frequency (data not shown; see Materials and Methods), suggesting that BDNF similarly elevates spontaneous presynaptic transmitter release at all three synapse types.

Differential BDNF effects on IPSCs at $\mathrm{I} \rightarrow \mathrm{I}$ and $\mathrm{I} \rightarrow \mathrm{E}$ synapses Changes in the amplitude of IPSCs or GABA-induced membrane currents may result from a change in membrane conductance or in the driving force for $\mathrm{Cl}^{-}$ions. Changes in membrane conductance could reflect presynaptic or postsynaptic modifications, e.g., changes in transmitter release or in response properties of $\mathrm{GABA}_{\mathrm{A}}$ receptors, respectively. Changes in the driving force, however, could result directly from changes in the postsynaptic $\mathrm{Cl}^{-}$concentration $\left(\left[\mathrm{Cl}^{-}\right]_{\mathrm{i}}\right)$, altering the reversal potential for IPSCs $\left(E_{\text {IPSC }}\right)$. To determine the mechanism underlying the 

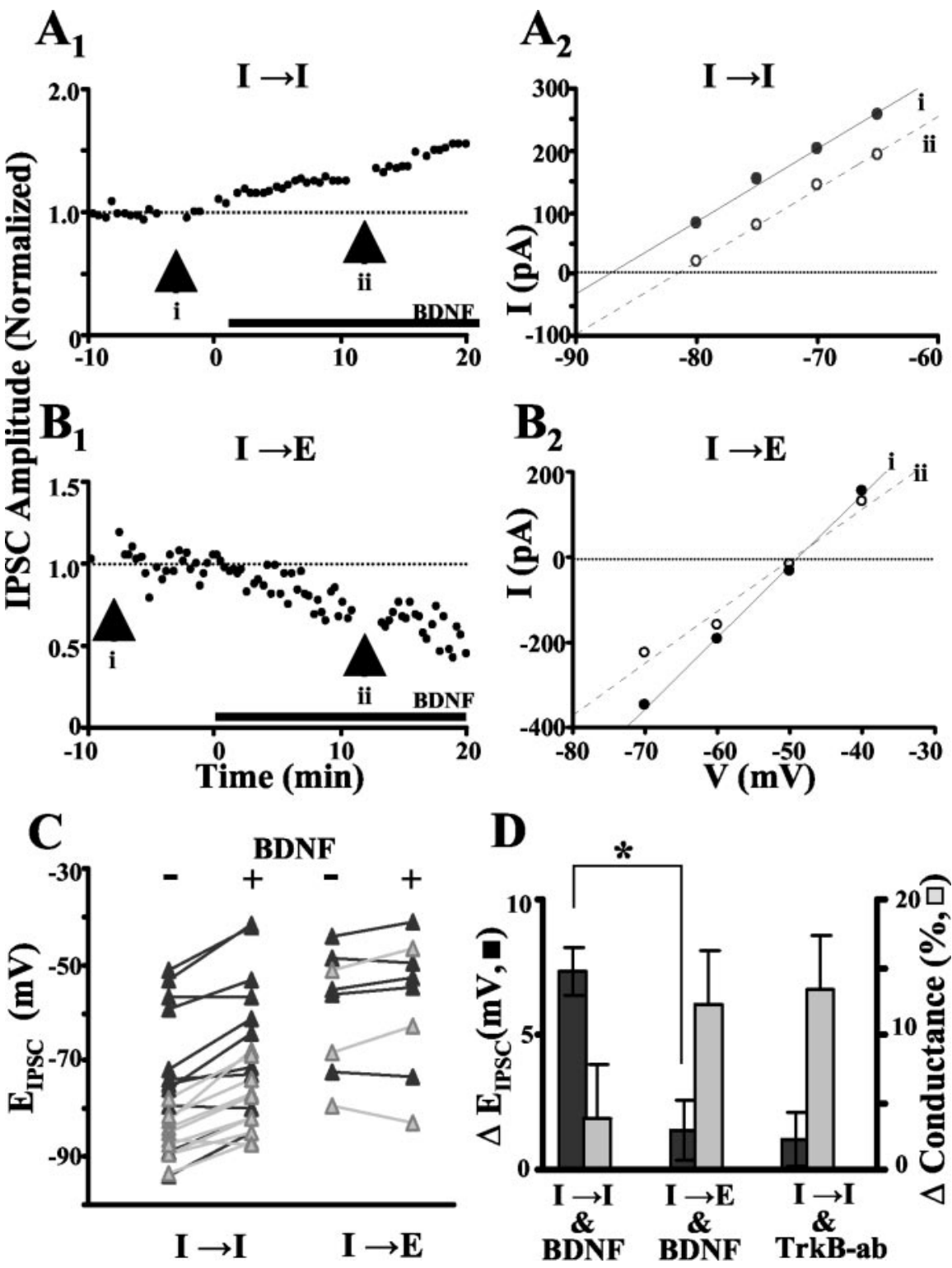

Figure 4. Differential BDNF effects on IPSCs at $\mathrm{I} \rightarrow \mathrm{I}$ and $\mathrm{I} \rightarrow \mathrm{E} . A, B$, Example of $\mathrm{IPSC}$ at $\mathrm{I} \rightarrow \mathrm{I}\left(A_{j}\right.$; gramicidin $\left.\mathrm{D}\right)$ and $\mathrm{I} \rightarrow \mathrm{E}\left(B_{j}\right.$; amphotericin B) before and after BDNF treatment (blackbar). At the times indicated ( $i$,ii; arrows), IPSC amplitudes were measured at different clamping voltages (in 5-10 mV steps) and plotted against the holding voltage in $A_{2}$ and $B_{2}$. The lines represent the best linear fit of data before (black line, black circles) and after (dashed line, white circles) BDNF treatment, its abscissa-intercept determines the $E_{\mathrm{IPSC}}$, and its slope is taken as the synaptic conductance. C, Summary plots showing $E_{\mathrm{IPSC}}$ at $\mathrm{I} \rightarrow \mathrm{I}$ and $\mathrm{I} \rightarrow \mathrm{E}$ synapses before $(-)$ and after $(+)$ BDNF treatment for individual recordings performed with gramicidin $D$ (gray triangles) or amphotericin $B$ (black triangles). There was no significant difference between data obtained by the two methods at either $\mathrm{I} \rightarrow \mathrm{I}$ or $\mathrm{I} \rightarrow$ E synapses ( $p=0.27$ and 0.42 , respectively; unpaired $t$ test). D, Summary plots of acute changes in $E_{\operatorname{IPSC}}$ (in millivolts) and decrease in synaptic conductance (percentage) after adding BDNF (100 ng/ml), at $\mathrm{I} \rightarrow \mathrm{I}(n=21)$ and $\mathrm{I} \rightarrow \mathrm{E}(n=8)$ synapses, or removing endogenous BDNF activity by adding TrkB antibody ( $2 \mu \mathrm{g} / \mathrm{ml} ; \operatorname{TrkB}-\mathrm{ab})$ at $\mathrm{I} \rightarrow \mathrm{I}$ synapses $(n=4)$. At $\mathrm{I} \rightarrow \mid \mathrm{v}$ versus $\mathrm{I} \rightarrow \mathrm{E}$, significant difference was found between the BDNF effects on $E_{\text {IPSC }}(p<0.0001$; unpaired $t$ test) but not between BDNF effects on conductance ( $p=0.12 ; t$ test). TrkB antibody had no significant acute effect on $E_{\mathrm{IPSC}}$ at $I \rightarrow I(p>0.1 ; t$ test).

postsynaptic BDNF effect on IPSCs, the total membrane conductance and $E_{\mathrm{IPSC}}$ were measured before and after BDNF treatment. During the control period and at 10-20 min after BDNF treatment, recordings of IPSCs were made at different membrane potentials from -80 to $-40 \mathrm{mV}$. The $I-V$ relationship was used to determine the slope conductance and $E_{\text {IPSC }}$ for each cell. Measurements were made for IPSCs recorded from both GABAergic and glutamatergic cells. As shown in Figure 4, BDNF caused a shift in $E_{\mathrm{IPSC}}$ toward more positive levels at $\mathrm{I} \rightarrow \mathrm{I}$ synapses (Fig. $4 A, C, D)$ but had no consistent effect on $E_{\mathrm{IPSC}}$ recorded at $\mathrm{I} \rightarrow \mathrm{E}$ synapses (Fig. $4 B-D$ ). We also noted that, although the $E_{\text {IPSC }}$ recorded showed a large cell-to-cell variation, BDNF consistently induced a similar degree of change in $E_{\mathrm{IPSC}}$ at $\mathrm{I} \rightarrow \mathrm{I}$ synapses (Fig. $4 C$ ). Thus, these postsynaptic GABAergic neurons appear to be more susceptible to $\left[\mathrm{Cl}^{-}\right]_{\mathrm{i}}$ modulation by BDNF than the glutamatergic neurons. We found an overall decrease in the slope conductance induced by BDNF at both synapse types, with a slightly larger decrease observed at $\mathrm{I} \rightarrow \mathrm{E}$ than $\mathrm{I} \rightarrow \mathrm{I}$ synapses, although the difference was not statistically significant (Fig. $4 D)$. These findings also account for the apparent difference in the BDNF effects on IPSCs versus mIPSCs at $\mathrm{I} \rightarrow$ I synapses described above. Shifts in $E_{\text {IPSC }}$ toward more positive values would increase the amplitude of inward IPSCs (recorded at -70 $\mathrm{mV}$ ) (Fig. 1C-E) and decrease the amplitude of outward mIPSCs (recorded at 0 $\mathrm{mV}$ ) (Fig. 3C,D).

A BDNF-induced modulation of $E_{\text {IPSC }}$ at $\mathrm{I} \rightarrow \mathrm{I}$ synapses raises the question of whether endogenous levels of BDNF are involved in maintaining or regulating $E_{\text {IPSC }}$. To test this, we recorded $E_{\text {IPSC }}$ from $\mathrm{I} \rightarrow \mathrm{I}$ synapses before and after acutely blocking endogenous BDNF activity using a TrkB receptor antibody specific to the extracellular domain of the receptor and shown previously to functionally block BDNF activation (Fig. 2C). Acutely blocking endogenous BDNF activity caused no significant change in $E_{\text {IPSC }}$ but caused a decrease in conductance (Fig. $4 D$ ). This suggests that acute change in the basal level of endogenous BDNF activity is not sufficient to modify $E_{\mathrm{IPSC}}$, although it may be sufficient to modify synaptic conductance. This finding does not rule out potential effects of higher levels of endogenously secreted BDNF on $E_{\text {IPSC }}$ under some physiological conditions, e.g., high-frequency neuronal firing (Balkowiec and Katz, 2002).

\section{BDNF-induced shift in $E_{\text {IPSC }}$ requires KCC2 activity}

The low $\left[\mathrm{Cl}^{-}\right]_{\mathrm{i}}$ characteristic of mature neurons is attributed primarily to KCC2 $\mathrm{K}^{+}-\mathrm{Cl}^{-}$cotransporter activity, which is known to be responsible for setting $E_{\text {IPSC }}$ (Thompson and Gahwiler, 1989; Kaila, 1994) and for the developmental switch of GABAergic transmission from excitation to inhibition (Owens et al., 1996; Ehrlich et al., 1999; Rivera et al., 1999; Ganguly et al., 2001). During development, increased expression and activation of $\mathrm{KCC} 2$, the $\mathrm{K}^{+}-\mathrm{Cl}^{-}$cotransporter predominant in neurons (Payne et al., 1996), lowers $\left[\mathrm{Cl}^{-}\right]_{\mathrm{i}}$ and drives $E_{\mathrm{IPSC}}$ toward more negative levels, resulting in inhibitory actions by GABA. To test whether KCC2 is involved in BDNF-induced modulation of IP- 
SCs, we treated hippocampal cultures with furosemide $(100 \mu \mathrm{m})$, an antagonist of $\mathrm{K}^{+}-\mathrm{Cl}^{-}$cotransporters (Thompson and Gahwiler, 1989; Payne et al., 1996; Payne, 1997; Jarolimek et al., 1999), for 10-15 min before the addition of BDNF. Furosemide treatment by itself caused a marked shift in $E_{\mathrm{IPSC}}$ toward more positive levels at $\mathrm{I} \rightarrow \mathrm{I}$ synapses, evidenced by a decrease in outward IPSC amplitude and an increase in inward IPSCs (Fig. 5A). Subsequent BDNF treatment, however, resulted in no additional alteration in IPSC amplitude or $E_{\mathrm{IPSC}}$ at these synapses, suggesting that furosemide-sensitive $\mathrm{K}^{+}-\mathrm{Cl}^{-}$cotransport is involved in the modulation of $E_{\text {IPSC }}$ by $\mathrm{BDNF}$ (Fig. $5 A, C$ ). In contrast, furosemide treatment by itself had no significant effect on $E_{\text {IPSC }}$ at $\mathrm{I} \rightarrow$ E synapses (Fig. $5 B$ ), and the effect of subsequent BDNF treatment on IPSCs was not altered by the presence of furosemide (Fig. $5 B, C$ ). These findings suggest that the postsynaptic modulatory action of BDNF at $\mathrm{I} \rightarrow \mathrm{I}$ synapses is mediated through downregulation of furosemide-sensitive $\mathrm{K}^{+}-\mathrm{Cl}^{-}$cotransport. On the basis of changes in $E_{\mathrm{IPSC}}$, we estimated that furosemide and BDNF increased $\left[\mathrm{Cl}^{-}\right]_{\mathrm{i}}$ to $169 \pm 6.8$ and $144 \pm$ $5.6 \%$ of the control value, respectively. These values are substantially lower than the variation of $\left[\mathrm{Cl}^{-}\right]_{\mathrm{i}}$ found in these neurons [up to fivefold difference between the lowest and highest $\left[\mathrm{Cl}^{-}\right]_{\mathrm{i}}$ as estimated from the range of $E_{\text {IPSC }}$ (Fig. $4 C$ )], suggesting that the absence of a BDNF effect in furosemide-treated cells was unlikely to be caused by a ceiling effect for $\left[\mathrm{Cl}^{-}\right]_{\mathrm{i}}$ elevation.

Furosemide is also known to block other cotransporters, including the $\mathrm{Na}^{+}-$ $\mathrm{K}^{+}-2 \mathrm{Cl}^{-}$cotransporter (NKCC) and $\mathrm{KCC} 1$. Therefore, to further determine whether the effect on $E_{\text {IPSC }}$ by furosemide was primarily attributable to a block of KCC2 activity, we tested the effect of furosemide on $E_{\mathrm{IPSC}}$ sensitivity to changes in external $\mathrm{K}^{+}\left(\left[\mathrm{K}^{+}\right]_{\mathrm{o}}\right)$. Changes in $\left[\mathrm{K}^{+}\right]_{\mathrm{o}}$ activate KCC2 but not NKCC or KCC1 (Payne, 1997; DeFazio et al., 2000). Thompson and Gahwiler (1989) have shown that $\left[\mathrm{K}^{+}\right]_{\mathrm{o}}$-induced changes in $E_{\text {IPSC }}$ do not result from other $\mathrm{K}^{+}$mediated components because blocking $\mathrm{K}^{+}$channels with intracellular $\mathrm{Cs}^{+}$does not block the $\left[\mathrm{K}^{+}\right]_{\mathrm{o}}$-induced effect on $E_{\text {IPSC }}$. Pairs of neurons, patched and identified as described previously, were recorded from for a control period in normal $\left[\mathrm{K}^{+}\right]_{\mathrm{o}}(3 \mathrm{~mm})$. A low $\left[\mathrm{K}^{+}\right]_{\mathrm{o}}(1 \mathrm{~mm})$ solution was then perfused into the culture. We found that this change in $\left[\mathrm{K}^{+}\right]_{\mathrm{o}}$ induced a significant decrease in $\left[\mathrm{Cl}^{-}\right]_{\mathrm{i}}$, as revealed by changes in IPSC amplitude and a shift in $E_{\text {IPSC }}$ toward a more negative level (Fig. 5D, top). The effect was reversed after the
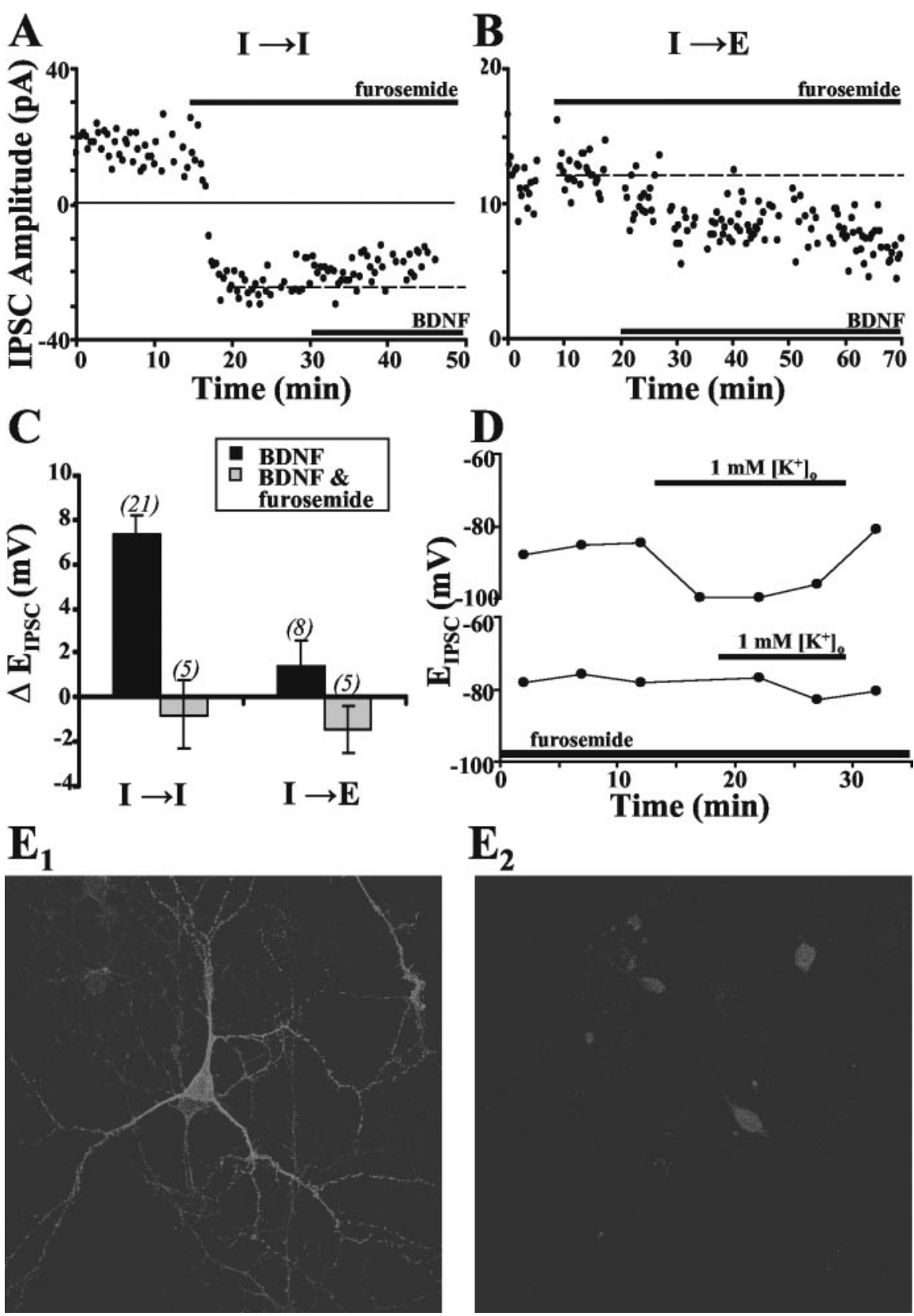

Figure 5. Effect of furosemide on BDNF-induced modulation of $E_{\mathrm{IPSC}} \cdot A, B$, Example recording of IPSCS (amphotericin $\mathrm{B}$ ) at $\mathrm{I} \rightarrow \mathrm{I}$ and $\mathrm{I} \rightarrow$ E synapses, showing the effects of furosemide $(100 \mu \mathrm{m})$ and subsequent BDNF treatment. The dashed line shows the mean IPSC amplitude during the last 10 min before adding BDNF. C, Summary plots comparing BDNF-induced changes in $E_{\text {IPSC }}$ in the absence (black) or presence (gray) of furosemide at $\mathrm{I} \rightarrow \mathrm{I}$ and $\mathrm{I} \rightarrow$ E synapses. Data obtained using both amphotericin $B$ and gramicidin D showed no difference and were thus pooled. D, Two example recordings (gramicidin D) showing changes in $E_{\mathrm{IPSC}}$ attributable to $\left[\mathrm{K}^{+}\right]_{0}$-induced activation of KCC2 cotransport in the absence (top) and presence (bottom) of furosemide. Normal $\left[\mathrm{K}^{+}\right]_{0}(3 \mathrm{~mm})$ was replaced with $1 \mathrm{~mm}\left[\mathrm{~K}^{+}\right]_{0}$ at the times indicated. $E$, Images of immunostained cells in hippocampal cultures. $E_{1}$, Specific staining for $\mathrm{KCC} 2$ in these neurons using a $\mathrm{KCC} 2$ antibody as the primary antibody with cell-to-cell variation in $\mathrm{KCC} 2$ staining intensity. $E_{2}$, Control staining in parallel cultures showing the level of nonspecific staining with the secondary antibody alone. For the control image, fluorescence intensity gain was increased more than twofold compared with that for specific KCC2 image. Nonspecific staining was restricted to the soma, showing no variation among neurons.

$\left[\mathrm{K}^{+}\right]_{\mathrm{o}}$ was returned to $3 \mathrm{~mm}$. In the presence of furosemide, reduction of $\left[\mathrm{K}^{+}\right]_{\mathrm{o}}$ had no effect on $\left[\mathrm{Cl}^{-}\right]_{\mathrm{i}}$ (Fig. $5 D$, bottom). These results are consistent with a prevalent furosemide-sensitive KCC2 cotransporter activity in these neurons. To further test for the presence of KCC2 in these neurons, immunocytochemical experiments were performed with a rabbit anti-KCC2 antibody. 

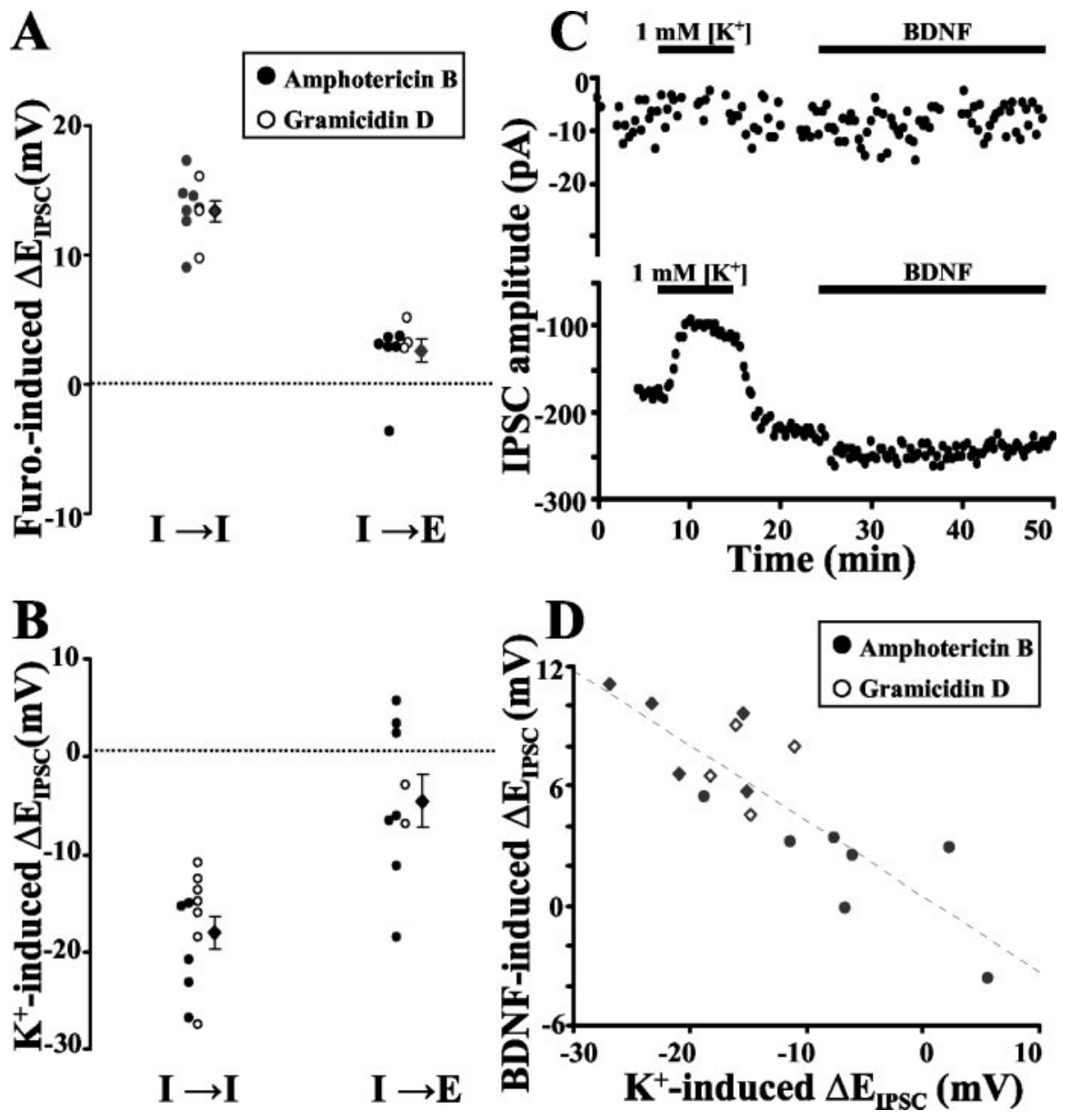

Figure 6. Changes in $E_{\text {IPSC }}$ induced by furosemide, $\left[\mathrm{K}^{+}\right]_{0}$, and BDNF. $A, B$, Scatter plots showing the effect of furosemide $(A)$ and changing $\left[\mathrm{K}^{+}\right]_{0}(B)$ on $E_{\mathrm{IPSC}}$ at $\mathrm{I} \rightarrow \mathrm{I}$ and $\mathrm{I} \rightarrow$ E synapses recorded with gramicidin $D$ (white circles) or amphotericin $\mathrm{B}$ (black circles). The change in $E_{\mathrm{IPSC}}$ is defined as the difference between $E_{\mathrm{IPSC}}$ measured during the control period and in the presence of furosemide $(A)$ or reduced $\left[\mathrm{K}^{+}\right]_{0}(1 \mathrm{~mm} ; B)$. C, Separate example recordings (amphotericin B) of IPSCs at two different synapses (top and bottom) showing responses to $\left[\mathrm{K}^{+}\right]_{0}$ and BDNF. Control periods were recorded with normal solution $\left(3 \mathrm{~mm}\left[\mathrm{~K}^{+}\right]_{0}\right.$, no $\mathrm{BDNF})$, and $\left[\mathrm{K}^{+}\right]_{0}$ was temporarily changed to $1 \mathrm{~mm}$ during time indicated. BDNF was added after the return to $3 \mathrm{~mm}\left[\mathrm{~K}^{+}\right]_{0}$. D, Scatter plot showing that the magnitudes of $\Delta E_{\text {IPSC }}$ induced by the reduction of $\left[\mathrm{K}^{+}\right]_{0}$ (to $1 \mathrm{mM}$ ) and by $\mathrm{BDNF}$ (at normal $\left[\mathrm{K}^{+}\right]_{0}$ ) at individual synapses are inversely correlated (correlation coefficient, $r=-0.841$; associated probability, $p<0.001$; ordinary least-squares regression). Recordings were made with amphotericin $B$ (white symbols) and gramicidin $D$ (black symbols) at both $\mathrm{I} \rightarrow \mathrm{I}$ (diamonds) and $\mathrm{I} \rightarrow \mathrm{E}$ (circles) synapses.

We found specific staining for KCC2 in these cultures, with a large cell-to-cell variation in the staining intensity within the same culture (Fig. 5E). This is consistent with a variable level of KCC2 expression among a heterogeneous population of neurons.

\section{BDNF effects on IPSCs correlate with KCC2 activity}

The above findings suggest that the effect on IPSCs by BDNF at $\mathrm{I} \rightarrow \mathrm{I}$ synapses involves modulation of KCC2 activity. To further test whether differences in the effects on IPSCs by BDNF at I $\rightarrow \mathrm{I}$ versus $\mathrm{I} \rightarrow$ E synapses result from differences in KCC2 activity, we compared the effects of either furosemide treatment or changing $\left[\mathrm{K}^{+}\right]_{\mathrm{o}}$ on $E_{\mathrm{IPSC}}$ at GABAergic and glutamatergic postsynaptic cells. Blocking $\mathrm{K}^{+}-\mathrm{Cl}^{-}$cotransporter activity with furosemide caused significant changes in $E_{\text {IPSC }}$ at GABAergic but not glutamatergic cells (Fig. 6A), suggesting that $\mathrm{I} \rightarrow \mathrm{I}$ and $\mathrm{I} \rightarrow$ E synapses differ by their postsynaptic $\mathrm{K}^{+}-\mathrm{Cl}^{-}$cotransporter activity. Furthermore, activating KCC2 cotransporters by changing $\left[\mathrm{K}^{+}\right]_{\mathrm{o}}$ caused significant changes in $E_{\mathrm{IPSC}}$ in GABAergic but not glutamatergic cells (Fig. $6 B$ ), more specifically indicating cell-type dif- ferences in KCC2 activity and not other furosemide-sensitive $\quad \mathrm{K}^{+}-\mathrm{Cl}^{-}$ cotransporters.

To determine whether the differences in KCC2 activity alone can account for the differences in BDNF-induced modulation of IPSCs observed at different synapse types, neuron pairs were recorded continuously under the following conditions. First, we recorded the shift in $E_{\text {IPSC }}$ induced by changing $\left[\mathrm{K}^{+}\right]_{\mathrm{o}}$ briefly from 3 to $1 \mathrm{~mm}$, to reveal KCC2 activity. After recording from the same cells for a second control period with $3 \mathrm{~mm}\left[\mathrm{~K}^{+}\right]_{\mathrm{o}}$, we treated the cells with BDNF and measured changes in $E_{\text {IPSC }}$ to determine the synapse susceptibility to BDNF-induced modulation (Fig. 6C). We found that the degree of $E_{\text {IPSC }}$ shift induced by low $\left[\mathrm{K}^{+}\right]_{\mathrm{o}}$, which reflects the activity of $\mathrm{KCC} 2$, correlated strongly with the BDNF responsiveness for each individual cell (Fig. 6D), at either $\mathrm{I} \rightarrow \mathrm{I}$ or $\mathrm{I} \rightarrow$ E synapses.

\section{Discussion}

In this study, we first show that, in hippocampal cultures, BDNF has different modulatory effects at glutamatergic and GABAergic synapses: enhancing the amplitude of EPSCs at E $\rightarrow$ E synapses but not that of IPSCs at I $\rightarrow$ E synapses. Additionally, BDNF has differential effects on IPSCs at $\mathrm{I} \rightarrow$ E versus $\mathrm{I} \rightarrow \mathrm{I}$ synapses. At $\mathrm{I} \rightarrow \mathrm{E}$ synapses, we found that BDNF slightly attenuated IPSC amplitude, apparently through a reduction of presynaptic evoked GABA release. At $\mathrm{I} \rightarrow \mathrm{I}$ synapses, however, BDNF modified the IPSC amplitude through a shift in $E_{\text {IPSC }}$ toward more positive levels, brought about by downregulating postsynaptic KCC2-mediated $\mathrm{K}^{+} / \mathrm{Cl}^{-}$cotransporter activity. The strong correlation between postsynaptic KCC2 activity and susceptibility to BDNF-induced modulation of $E_{\text {IPSC }}$ further suggests KCC2 regulation as a primary postsynaptic mechanism underlying the target cell specificity of the effect on GABAergic synapses by BDNF.

\section{Differential BDNF effects on EPSCs and IPSCs}

Our findings of the modulatory effects of BDNF at $\mathrm{E} \rightarrow \mathrm{E}$ and $\mathrm{I} \rightarrow \mathrm{E}$ synapses are in general agreement with previous reports on neurotrophin-induced acute synaptic modifications in dissociated cell cultures and slice preparations (Poo, 2001). Although several reports have shown that BDNF does not acutely modify basal glutamatergic synaptic transmission in slice preparations (Figurov et al., 1996; Tanaka et al., 1997; Frerking et al., 1998), the discrepancy may reflect differences in the experimental conditions or developmental stages of the preparations (Poo, 2001). For example, BDNF-induced effects on EPSCs were found to depend on synapse maturity, as gauged by the initial synaptic strength and reliability (Berninger et al., 1999; Schinder et al., 2000). Previous reports on acute synaptic modulation by neurotrophins have, in general, examined either EPSCs or IPSCs but 
not both in the same preparation. The present study demonstrates that, for the same developmental stage and experimental conditions, BDNF directly exerts differential synaptic effects by potentiating $\mathrm{E} \rightarrow \mathrm{E}$ and suppressing $\mathrm{I} \rightarrow \mathrm{E}$ transmission.

\section{Postsynaptic cell-type specificity}

Synaptic modifications have been shown to be specific to the postsynaptic cell type in a number of systems. In hippocampal culture and slice, activity-dependent LTP can be induced at E $\rightarrow \mathrm{E}$ but not $\mathrm{E} \rightarrow \mathrm{I}$ synapses (Bi and Poo, 1998; Maccaferri et al., 1998, respectively), apparently attributable to the lack of postsynaptic $\mathrm{Ca}^{2+}$ /calmodulin kinase II in GABAergic cells (Liu and Jones, 1997; Sik et al., 1998). Similarly, acute BDNF application potentiates presynaptic transmitter release at $\mathrm{E} \rightarrow \mathrm{E}$ but not $\mathrm{E} \rightarrow \mathrm{I}$ synapses (Schinder et al., 2000), perhaps attributable to a modification of presynaptic terminal susceptibility to neurotrophins through retrograde signaling from the postsynaptic cell. We demonstrated that the effect on IPSCs by BDNF also depends on postsynaptic cell type. The presynaptic and postsynaptic cell-type specificity of the effects of BDNF could play a critical role in maintaining coordinated modifications of excitatory and inhibitory synaptic actions in heterogeneous neuronal populations during development and in mature nervous systems. This targetcell specificity may reflect differences in inhibitory synapse maturation at $\mathrm{I} \rightarrow \mathrm{I}$ versus $\mathrm{I} \rightarrow$ E synapses, and maturation of inhibitory synapses has been shown to correlate with increased KCC2 expression and to depend on GABAergic activity (Ganguly et al., 2001).

\section{Presynaptic versus postsynaptic mechanisms}

Previous reports have shown that BDNF effects on EPSCs result primarily from increased presynaptic transmitter release (Lohof et al., 1993; Lessmann and Heumann, 1998; Li et al., 1998; Berninger et al., 1999). However, BDNF effects on IPSCs have been attributed to both presynaptic and postsynaptic mechanisms. Frerking et al. (1998) found that the reduction of inhibitory transmission by BDNF was accompanied by changes in mean variance and paired-pulse depression, indications of presynaptic effects. However, Tanaka et al. (1997) showed that the effect on IPSCs by BDNF depends on postsynaptic tyrosine kinase activity and $\mathrm{Ca}^{2+}$ mobilization, and Brunig et al. (2001) reported BDNF-induced downregulation of $\mathrm{GABA}_{\mathrm{A}}$ receptor surface expression. Here we showed that BDNF modulation of IPSCs at $\mathrm{I} \rightarrow \mathrm{E}$ synapses most likely results from presynaptic actions that reduce efficacy of GABA release, whereas at $\mathrm{I} \rightarrow \mathrm{I}$ synapses, it is primarily attributable to a postsynaptic shift of $E_{\text {IPSC }}$ to more positive levels. We found that BDNF increased frequency of both mEPSCs and mIPSCs, indicating an increase in the presynaptic release probability. This is consistent with the BDNFinduced enhancement of EPSCs at $\mathrm{E} \rightarrow \mathrm{E}$ synapses but not reduction of IPSCs at I $\rightarrow$ E synapses, suggesting differential regulation of spontaneous and evoked GABA release by BDNF. Schinder et al. (2000) have shown previously in these cultures that BDNF had no effect on evoked synaptic responses but caused an increase in mEPSC frequency at $\mathrm{E} \rightarrow \mathrm{I}$ synapses. Interestingly, in synaptotagmin-deficient neurons, increased mEPSC frequency accompanied reduced evoked transmitter release (Broadie et al., 1994). Opposite BDNF effects on spontaneous and evoked release at $\mathrm{I} \rightarrow \mathrm{E}$ synapses may reflect presynaptic regulation of synaptic vesicle proteins, resulting in release modulation similar to that found in synatotagmin-deficient neurons.

In addition to the BDNF-induced changes in presynaptic transmitter release observed at $\mathrm{E} \rightarrow \mathrm{E}, \mathrm{I} \rightarrow \mathrm{E}$, and $\mathrm{I} \rightarrow \mathrm{I}$ synapses, we also observed BDNF-induced changes in mini amplitude only at $\mathrm{I} \rightarrow$ I synapses, indicative of a postsynaptic BDNF effect at $\mathrm{I} \rightarrow \mathrm{I}$ synapses. Recordings of $I_{\mathrm{GABA}}$ further confirmed the existence of a postsynaptic BDNF effect independently functioning to selectively modulate $I_{\mathrm{GABA}}$ at GABAergic cells. The existence of celltype-specific modulation and both presynaptic and postsynaptic BDNF effects allows diverse physiological actions of BDNF on neural networks made of a heterogeneous population of neurons.

\section{BDNF regulates postsynaptic $\left[\mathrm{Cl}^{-}\right]_{\mathrm{i}}$ at $\mathrm{GABAergic}$ synapses}

At $\mathrm{I} \rightarrow \mathrm{I}$ synapses, BDNF caused a shift in $E_{\text {IPSC }}$ toward more positive levels through postsynaptic regulation of a furosemidesensitive $\mathrm{Cl}^{-}$transporter activity. Previous studies have shown that $\mathrm{Cl}^{-}$transport plays a critical role in the development of inhibitory synapses (Owens et al., 1996; Ehrlich et al., 1999; Rivera et al., 1999; Ganguly et al., 2001) and in maintaining $\mathrm{Cl}^{-}$ homeostasis in mature neurons (Jarolimek et al., 1999). In many developing nervous systems, age-specific expression of different $\mathrm{K}^{+}-\mathrm{Cl}^{-}$cotransporters renders GABAergic synaptic transmission initially depolarizing and later hyperpolarizing (Ben-Ari, 2002). Early in development, high NKCC expression levels elevate $\left[\mathrm{Cl}^{-}\right]_{\mathrm{i}}$ (Fukuda et al., 1998; Kakazu et al., 1999). Later, NKCC levels are reduced and KCC2 expression is upregulated, lowering $\left[\mathrm{Cl}^{-}\right]_{\mathrm{i}}$ and causing a shift of $E_{\mathrm{IPSC}}$ toward more negative levels (Ehrlich et al., 1999). After GABAergic transmission switches from depolarizing to hyperpolarizing, KCC2 normally maintains low $\left[\mathrm{Cl}^{-}\right]_{\mathrm{i}}$. However, studies on mature neurons have also shown that the efficacy of GABAergic transmission may be altered through modulation of $\mathrm{K}^{+}-\mathrm{Cl}^{-}$cotransport and subsequent changes in $\left[\mathrm{Cl}^{-}\right]_{\mathrm{i}}$. Thompson and Gahwiler (1989) showed that, in hippocampal slice cultures, repetitive lowfrequency stimulation, furosemide treatment, or changes in $\left[\mathrm{K}^{+}\right]_{\mathrm{o}}$ all caused a similar reduction in the efficacy of GABAergic synapses through changes in both conductance and driving force for $\mathrm{Cl}^{-}$. Later studies have shown that both furosemide treatment and $\left[\mathrm{K}^{+}\right]_{\mathrm{o}}$ can affect KCC2 activity (Payne, 1997). Furosemide is also known to act on other cotransporters, including NKCC. However, it is unlikely that the furosemide effect observed in the present study results from a block of NKCC activity, because blocking NKCC would result in a decreased $\left[\mathrm{Cl}^{-}\right]_{\mathrm{i}}$, and thus a shift of $E_{\text {IPSC }}$ toward more negative rather than positive levels. Furthermore, the hippocampal cultures used for these experiments have already been shown to predominantly express KCC2 (Ganguly et al., 2001). Rivera et al. (2002) have reported recently that, over the time course of hours, BDNF modulates GABAergic synaptic transmission through a downregulation of KCC2 mRNA and protein. The acute downregulation of $\mathrm{K}^{+}-\mathrm{Cl}^{-}$ cotransporter activity within $10 \mathrm{~min}$ after BDNF application that we observed appears to involve more rapid posttranslational regulation, although a rapid BDNF-dependent modulation of protein synthesis remains possible (Aakalu et al., 2001).

The postsynaptic specificity of the effect of BDNF could result from differences in postsynaptic TrkB expression. Although previous studies have shown that TrkB expression levels in the hippocampus remain constant from E17 through adulthood (Ivanova and Beyer, 2001), cell-to-cell variation in TrkB expression could still arise from varied histories of activity and exposure to BDNF (Haapasalo et al., 2002). Nonetheless, differences in TrkB expression patterns are unlikely to be the main cause for specificity of BDNF at GABAergic synapses, because the magnitude of the effect of BDNF directly correlates with KCC2 activity levels, as revealed by $\left[\mathrm{K}^{+}\right]_{\mathrm{o}}$-sensitive $\mathrm{Cl}^{-}$transporter activity. 
Expression and activity of KCC2 varies with developmental stage (Lu et al., 1999; DeFazio et al., 2000), neuronal type (Ueno et al., 2002), and presence of GABAergic activity (Ganguly et al., 2001). The dependence of KCC2 activity on such diverse factors creates a scenario in which the differential effects on GABAergic synapses by BDNF are specific not only to KCC2 activity but also to the varied factors impinging on KCC2 expression and activity.

BDNF and other neurotrophins are involved in a variety of critical nervous system functions, ranging from neuronal development and survival to learning and memory. In addition, they have been linked to pathological conditions such as epilepsy (Esclapez et al., 1997; Biagini et al., 2001; Binder et al., 2001; Scharfman et al., 2002). Interestingly, previous studies have also shown the importance of $\mathrm{Cl}^{-}$transport in epilepsy and other pathological conditions, including axonal injury (Nabekura et al., 2002). Here, we report a link between neurotrophin activity and $\mathrm{Cl}^{-}$ transport at GABAergic synapses that provides a promising lead for additional investigation on the regulation of inhibitory mechanisms involved in these pathological conditions.

\section{References}

Aakalu G, Smith WB, Nguyen N, Jiang C, Schuman EM (2001) Dynamic visualization of local protein synthesis in hippocampal neurons. Neuron 30:489-502.

Akaneya Y, Tsumoto T, Kinoshita S, Hatanaka H (1997) Brain-derived neurotrophic factor enhances long-term potentiation in rat visual cortex. J Neurosci 17:6707-6716.

Balkowiec A, Katz DM (2002) Cellular mechanisms regulating activitydependent release of native brain-derived neurotrophic factor from hippocampal neurons. J Neurosci 22:10399-10407.

Ben-Ari Y (2002) Excitatory actions of GABA during development: the nature of the nurture. Nat Rev Neurosci 3:728-739.

Berninger B, Schinder AF, Poo MM (1999) Synaptic reliability correlates with reduced susceptibility to synaptic potentiation by brain-derived neurotrophic factor. Learn Mem 6:232-242.

Bi GQ, Poo MM (1998) Synaptic modifications in cultured hippocampal neurons: dependence on spike timing, synaptic strength, and postsynaptic cell type. J Neurosci 18:10464-10472.

Biagini G, Avoli M, Marcinkiewicz J, Marcinkiewicz M (2001) Brainderived neurotrophic factor superinduction parallels anti-epileptic-neuroprotective treatment in the pilocarpine epilepsy model. J Neurochem 76:1814-1822.

Binder DK, Croll SD, Gall CM, Scharfman HE (2001) BDNF and epilepsy: too much of a good thing? Trends Neurosci 24:47-53.

Brandon NJ, Jovanovic JN, Smart TG, Moss SJ (2002) Receptor for activated $\mathrm{C}$ kinase- 1 facilitates protein kinase $\mathrm{C}$-dependent phosphorylation and functional modulation of $\mathrm{GABA}_{\mathrm{A}}$ receptors with the activation of G-protein-coupled receptors. J Neurosci 22:6353-6361.

Broadie K, Bellen HJ, DiAntonio A, Littleton JT, Schwarz TL (1994) Absence of synaptotagmin disrupts excitation-secretion coupling during synaptic transmission. Proc Natl Acad Sci USA 91:10727-10731.

Brunig I, Penschuck S, Berninger B, Benson J, Fritschy JM (2001) BDNF reduces miniature inhibitory postsynaptic currents by rapid downregulation of $\operatorname{GABA}(\mathrm{A})$ receptor surface expression. Eur J Neurosci 13:1320-1328.

DeFazio RA, Keros S, Quick MW, Hablitz JJ (2000) Potassium-coupled chloride cotransport controls intracellular chloride in rat neocortical pyramidal neurons. J Neurosci 20:8069-8076.

Dunne EL, Moss SJ, Smart TG (1998) Inhibition of GABA $A_{\mathrm{A}}$ receptor function by tyrosine kinase inhibitors and their inactive analogues. Mol Cell Neurosci 12:300-310.

Ehrlich I, Lohrke S, Friauf E (1999) Shift from depolarizing to hyperpolarizing glycine action in rat auditory neurones is due to age-dependent $\mathrm{Cl}-$ regulation. J Physiol (Lond) 520:121-137.

Esclapez M, Hirsch JC, Khazipov R, Ben-Ari Y, Bernard C (1997) Operative GABAergic inhibition in hippocampal CA1 pyramidal neurons in experimental epilepsy. Proc Natl Acad Sci USA 94:12151-12156.

Figurov A, Pozzo-Miller LD, Olafsson P, Wang T, Lu B (1996) Regulation of synaptic responses to high-frequency stimulation and LTP by neurotrophins in the hippocampus. Nature 381:706-709.
Frerking M, Malenka RC, Nicoll RA (1998) Brain-derived neurotrophic factor (BDNF) modulates inhibitory, but not excitatory, transmission in the CA1 region of the hippocampus. J Neurophysiol 80:3383-3386.

Fukuda A, Muramatsu K, Okabe A, Shimano Y, Hida H, Fujimoto I, Nishino $\mathrm{H}$ (1998) Changes in intracellular $\mathrm{Ca}^{2+}$ induced by $\mathrm{GABA}_{\mathrm{A}}$ receptor activation and reduction in $\mathrm{Cl}^{-}$gradient in neonatal rat neocortex. J Neurophysiol 79:439-446.

Ganguly K, Schinder AF, Wong ST, Poo M (2001) GABA itself promotes the developmental switch of neuronal GABAergic responses from excitation to inhibition. Cell 105:521-532.

Haapasalo A, Sipola I, Larsson K, Akerman KE, Stoilov P, Stamm S, Wong G, Castren E (2002) Regulation of TRKB surface expression by brainderived neurotrophic factor and truncated TRKB isoforms. J Biol Chem 277:43160-43167.

Ivanova T, Beyer C (2001) Pre- and postnatal expression of brain-derived neurotrophic factor $\mathrm{mRNA} /$ protein and tyrosine protein kinase receptor B mRNA in the mouse hippocampus. Neurosci Lett 307:21-24.

Jarolimek W, Lewen A, Misgeld U (1999) A furosemide-sensitive $\mathrm{K}^{+}{ }_{-} \mathrm{Cl}^{-}$ cotransporter counteracts intracellular $\mathrm{Cl}^{-}$accumulation and depletion in cultured rat midbrain neurons. J Neurosci 19:4695-4704.

Jovanovic JN, Benfenati F, Siow YL, Sihra TS, Sanghera JS, Pelech SL, Greengard P, Czernik AJ (1996) Neurotrophins stimulate phosphorylation of synapsin I by MAP kinase and regulate synapsin I-actin interactions. Proc Natl Acad Sci USA 93:3679-3683.

Jovanovic JN, Czernik AJ, Fienberg AA, Greengard P, Sihra TS (2000) Synapsins as mediators of BDNF-enhanced neurotransmitter release. Nat Neurosci 3:323-329.

Kaila K (1994) Ionic basis of $\mathrm{GABA}_{\mathrm{A}}$ receptor channel function in the nervous system. Prog Neurobiol 42:489-537.

Kakazu Y, Akaike N, Komiyama S, Nabekura J (1999) Regulation of intracellular chloride by cotransporters in developing lateral superior olive neurons. J Neurosci 19:2843-2851.

Kang H, Schuman EM (1995) Long-lasting neurotrophin-induced enhancement of synaptic transmission in the adult hippocampus. Science 267:1658-1662.

Kelsch W, Hormuzdi S, Straube E, Lewen A, Monyer H, Misgeld U (2001) Insulin-like growth factor 1 and a cytosolic tyrosine kinase-activate chloride outward transport during maturation of hippocampal neurons. J Neurosci 21:8339-8347.

Kim HG, Wang T, Olafsson P, Lu B (1994) Neurotrophin 3 potentiates neuronal activity and inhibits gamma-aminobutyratergic synaptic transmission in cortical neurons. Proc Natl Acad Sci USA 91:12341-12345.

Korte M, Carroll P, Wolf E, Brem G, Thoenen H, Bonhoeffer T (1995) Hippocampal long-term potentiation is impaired in mice lacking brainderived neurotrophic factor. Proc Natl Acad Sci USA 92:8856-8860.

Kovalchuk Y, Hanse E, Kafitz KW, Konnerth A (2002) Postsynaptic induction of BDNF-mediated long-term potentiation. Science 295:1729-1734.

Kyrozis A, Reichling DB (1995) Perforated-patch recording with gramicidin avoids artifactual changes in intracellular chloride concentration. J Neurosci Methods 57:27-35.

Lessmann V, Heumann R (1998) Modulation of unitary glutamatergic synapses by neurotrophin- $4 / 5$ or brain-derived neurotrophic factor in hippocampal microcultures: presynaptic enhancement depends on preestablished paired-pulse facilitation. Neuroscience 86:399-413.

Lessmann V, Gottmann K, Heumann R (1994) BDNF and NT-4/5 enhance glutamatergic synaptic transmission in cultured hippocampal neurones. NeuroReport 6:21-25.

Levi-Montalcini R (1987) The nerve growth factor 35 years later. Science 237:1154-1162.

Levine ES, Dreyfus CF, Black IB, Plummer MR (1995) Brain-derived neurotrophic factor rapidly enhances synaptic transmission in hippocampal neurons via postsynaptic tyrosine kinase receptors. Proc Natl Acad Sci USA 92:8074-8077.

Lewin GR, Barde YA (1996) Physiology of the neurotrophins. Annu Rev Neurosci 19:289-317.

Li YX, Zhang Y, Lester HA, Schuman EM, Davidson N (1998) Enhancement of neurotransmitter release induced by brain-derived neurotrophic factor in cultured hippocampal neurons. J Neurosci 18:10231-10240.

Liou JC, Yang RS, Fu WM (1997) Regulation of quantal secretion by neurotrophic factors at developing motoneurons in Xenopus cell cultures. J Physiol (Lond) 503:129-139.

Liu X, Jones EG (1997) Alpha isoform of calcium-calmodulin dependent 
protein kinase II (CAM II kinase-alpha) restricted to excitatory synapses in the CA1 region of rat hippocampus. NeuroReport 8:1475-1479.

Loeb JA, Hmadcha A, Fischbach GD, Land SJ, Zakarian VL (2002) Neuregulin expression at neuromuscular synapses is modulated by synaptic activity and neurotrophic factors. J Neurosci 22:2206-2214.

Lohof AM, Ip NY, Poo MM (1993) Potentiation of developing neuromuscular synapses by the neurotrophins NT-3 and BDNF. Nature 363:350-353.

Lu J, Karadsheh M, Delpire E (1999) Developmental regulation of the neuronal-specific isoform of $\mathrm{K}-\mathrm{Cl}$ cotransporter $\mathrm{KCC} 2$ in postnatal rat brains. J Neurobiol 39:558-568.

Maccaferri G, Toth K, McBain CJ (1998) Target-specific expression of presynaptic mossy fiber plasticity. Science 279:1368-1370.

McAllister AK, Katz LC, Lo DC (1999) Neurotrophins and synaptic plasticity. Annu Rev Neurosci 22:295-318.

McMahon LL, Kauer JA (1997) Hippocampal interneurons express a novel form of synaptic plasticity. Neuron 18:295-305.

Messaoudi E, Bardsen K, Srebro B, Bramham CR (1998) Acute intrahippocampal infusion of BDNF induces lasting potentiation of synaptic transmission in the rat dentate gyrus. J Neurophysiol 79:496-499.

Nabekura J, Ueno T, Okabe A, Furuta A, Iwaki T, Shimizu-Okabe C, Fukuda A, Akaike N (2002) Reduction of KCC2 expression and $\mathrm{GABA}_{\mathrm{A}}$ receptor-mediated excitation after in vivo axonal injury. J Neurosci 22:4412-4417.

Narisawa-Saito M, Carnahan J, Araki K, Yamaguchi T, Nawa H (1999) Brain-derived neurotrophic factor regulates the expression of AMPA receptor proteins in neocortical neurons. Neuroscience 88:1009-1014.

Owens DF, Boyce LH, Davis MB, Kriegstein AR (1996) Excitatory GABA responses in embryonic and neonatal cortical slices demonstrated by gramicidin perforated-patch recordings and calcium imaging. J Neurosci 16:6414-6423

Patterson SL, Abel T, Deuel TA, Martin KC, Rose JC, Kandel ER (1996) Recombinant BDNF rescues deficits in basal synaptic transmission and hippocampal LTP in BDNF knockout mice. Neuron 16:1137-1145.

Payne JA (1997) Functional characterization of the neuronal-specific K-Cl cotransporter: implications for $\left[\mathrm{K}^{+}\right]_{0}$ regulation. Am J Physiol 273:C1516-C1525.

Payne JA, Stevenson TJ, Donaldson LF (1996) Molecular characterization of a putative $\mathrm{K}-\mathrm{Cl}$ cotransporter in rat brain. A neuronal-specific isoform. J Biol Chem 271:16245-16252.

Poo MM (2001) Neurotrophins as synaptic modulators. Nat Rev Neurosci 2:24-32.

Rivera C, Voipio J, Payne JA, Ruusuvuori E, Lahtinen H, Lamsa K, Pirvola U, Saarma M, Kaila K (1999) The $\mathrm{K}^{+} / \mathrm{Cl}^{-}$co-transporter KCC2 renders GABA hyperpolarizing during neuronal maturation. Nature 397:251-255.

Rivera C, Li H, Thomas-Crusells J, Lahtinen H, Viitanen T, Nanobashvili A, Kokaia Z, Airaksinen MS, Voipio J, Kaila K, Saarma M (2002) BDNFinduced TrkB activation down-regulates the $\mathrm{K}^{+}-\mathrm{Cl}^{-}$cotransporter KCC2 and impairs neuronal $\mathrm{Cl}^{-}$extrusion. J Cell Biol 159:747-752.

Scharfman HE, Goodman JH, Sollas AL, Croll SD (2002) Spontaneous limbic seizures after intrahippocampal infusion of brain-derived neurotrophic factor. Exp Neurol 174:201-214.

Schinder AF, Berninger B, Poo M (2000) Postsynaptic target specificity of neurotrophin-induced presynaptic potentiation. Neuron 25:151-163.

Sik A, Hajos N, Gulacsi A, Mody I, Freund TF (1998) The absence of a major $\mathrm{Ca}^{2+}$ signaling pathway in GABAergic neurons of the hippocampus. Proc Natl Acad Sci USA 95:3245-3250.

Tanaka T, Saito H, Matsuki N (1997) Inhibition of $\mathrm{GABA}_{\mathrm{A}}$ synaptic responses by brain-derived neurotrophic factor (BDNF) in rat hippocampus. J Neurosci 17:2959-2966.

Thompson SM, Gahwiler BH (1989) Activity-dependent disinhibition. II. Effects of extracellular potassium, furosemide, and membrane potential on $\mathrm{E}_{\mathrm{Cl}-}$ in hippocampal CA3 neurons. J Neurophysiol 61:512-523.

Ueno T, Okabe A, Akaike N, Fukuda A, Nabekura J (2002) Diversity of neuron-specific $\mathrm{K}^{+}-\mathrm{Cl}^{-}$cotransporter expression and inhibitory postsynaptic potential depression in rat motoneurons. J Biol Chem 277:4945-4950.

Wang T, Xie K, Lu B (1995) Neurotrophins promote maturation of developing neuromuscular synapses. J Neurosci 15:4796-4805.

Yang F, He X, Feng L, Mizuno K, Liu XW, Russell J, Xiong WC, Lu B (2001) PI-3 kinase and IP3 are both necessary and sufficient to mediate NT3induced synaptic potentiation. Nat Neurosci 4:19-28.

Zhang X, Poo MM (2002) Localized synaptic potentiation by BDNF requires local protein synthesis in the developing axon. Neuron 36:675688. 